\title{
Management Practices, Constraints, Opportunities and Marketing Systems of Village Chicken Production in Central Ethiopia
}

\author{
Tena Alemu \\ Department of Animal Production and Technology, Wolkite University, Ethiopia
}

\begin{abstract}
The study was conducted to assess management practices, constraints, opportunities and marketing systems of village chicken production in central Ethiopia, using questionnaire on 90 households. Both primary and secondary data was collected with interviewing the farmers by using semi-structured questionnaires, understanding their socio-economic characteristics and production system, feed resources, and housing system then the data was analyzed by using descriptive statistics. The dominant chicken production system in the study area was extensive system $(90.0 \%)$. Seasonal supplementary feeding $(63.4 \%)$ of home grown grains. $62.2 \%$ of respondent provides water for chicken and $(73.3 \%)$ of the respondents do not construct a separate house to their chickens. The purpose of rearing chicken were sources of income (66.7\%) and followed by home consumption (32.2\%) and both consumption and income (1.1\%). In the study area $87.8 \%$ of women share the responsibility of chicken feeding, watering and selling in the market. The main sources of feed for chicken were maize $(63.4 \%)$ and amicho $(32.2 \%)$. The main constraints of village chicken production were housing, predator, diseases, feed shortage and management. The main predator and disease for chicken were shelemetmat $(78.9 \%)$ and New Castle Disease $(77.8 \%)$. It was concluded that exertions should be made to better health care, husbandry practice, extension service and breeding to increase productivity of chicken at village management system. So that by considering situations identified management and production system and give attention for disease control, marketing systems, use of alternative management, marketing situation and providing training to be successful in village chicken production.
\end{abstract}

Index Terms- village chicken, constraint, management, marketing, opportunities, production.

DOI: $10.7176 / F S Q M / 98-05$

Publication date:June $30^{\text {th }} 2020$

\section{I.INTRODUCION}

Animal production in general and chicken production in particular plays an important socioeconomic role for people living in low income countries like Ethiopian ${ }^{[1]}$. Ethiopia is one of the Sub-Saharan African countries where most of the national economy depends on agriculture ${ }^{[2]}$. In most developing countries rural poultry play significant roles of improving the nutritional status, income, food security and livelihood of many smallholders ${ }^{[3]}$.

Village poultry production based mainly on a scavenging system is of enormous socio-economic significance, in terms of contribution to family nutrition and household food security throughout the developing world ${ }^{[4]}$. Although there is overwhelming evidence that family poultry production plays a vital role in the socio-cultural, economic and nutritional aspects of the livelihood of rural households have paid limited attention to its development and promotion. According to Addo, financial support, marketing, administration, coordination and technical support are among issues that affect family poultry development ${ }^{[5]}$.

In Ethiopia, village chickens are an integral component of the farming system of nearly all rural families, and they account for about $99 \%$ of the poultry production system ${ }^{[6]}$ and for more than $90 \%$ of the chicken and egg output of the country ${ }^{[7]}$. Village chicken production hysterics quite well with the conditions of rural households due to small feed cost, space requirement and low price of the animals ${ }^{[8]}$. In addition, Dhuguma indicated that the local chicken sector constitutes a significant contribution to human livelihood by being affordable sources of animal protein and contributes significantly to food security of poor households ${ }^{[9]}$.

Development of successful production strategies for poultry rearing depends on an accurate description of village chicken production systems ${ }^{[10]}$. Even if, Ethiopia owned huge chicken flock; there are different factors like diseases, predators, management, and lack of proper healthcare, feed source and poor marketing information that hinder the productivity of the chickens in most area of the country. Among the above obstacles, the poultry diseases are the main constraints implicated for reduction of total numbers and compromised productivity ${ }^{[11]}$. Developing schemes that aim to promote and improve the village poultry sub-sector need to incorporate indigenous knowledge

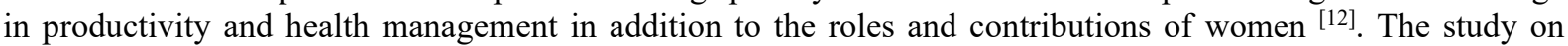
village poultry production may reveal different and more information on production system, constraints and opportunities.

Village chicken production system in Ethiopia is characterized by small flock size owned by individual households and are maintained under scavenging system with little or no inputs for housing, feeding or health care, 
low outputs, and periodic devastation of the flocks by disease ${ }^{[13]}$. The most serious problems facing birds of early age are inadequate environment and managements. Chicks suffer from high temperature, low humidity and lack of ventilation ${ }^{[14]}$. Therefore, the objective of the study was to assess village chicken production, management practices, constraints, opportunities and marketing system in the study area.

\section{MATERIALS AND METHODS}

\section{A. Description of the Study Area}

The study was conducted in Cheha districts. The district is located in Gurage Zone of central Ethiopia. The capital of the district, Emdiber, is located at $188 \mathrm{~km}$ south of Addis Ababa on the way to Wolkite town, the capital of the Zone. The geographical location of the study area extends from $8^{\circ} 00^{\prime} 18.9^{\prime \prime}$ to $8^{\circ} 15^{\prime} 28.53^{\prime \prime} \mathrm{N}$ and $37^{\circ} 35^{\prime} 46.48^{\prime \prime}$ to $38^{\circ} 03^{\prime} 59.59^{\prime \prime} \mathrm{E}$ at an elevation ranging from 900 to 2812 meters above sea level (masl). It has a total area of $573,13.85$ ha of which 40,190 ha are cultivated. The district constitutes 38 rural kebeles. As it is true to the other parts of Ethiopia, rainfall and temperature conditions depend on elevation. The average annual rain fall of the area is about $1,268.04 \mathrm{~mm}$ and the average maximum and minimum temperature in the study area is $24.97^{\circ} \mathrm{C}$ and $10.69^{\circ} \mathrm{C}$, respectively.

\section{B. Methods of Data Collection}

In order to achieve the objective of the study both primary and secondary sources of data were used. Primary data were collected through interview, personnel observation, and through distributing a semi-structured questionnaire which comprised of backyard chicken households, extension services, development agents, key information. Secondary data were collected from published and unpublished documents from Woreda's Livestock and Fishery Resources Sector.

\section{Sampling Size and Sampling Technique}

Three kebeles from Cheha woreda (Yefekterek Endebera; Wurerber and Buchach) were purposively selected from woreda based on accessibility of road and transport and chicken production potential. Before the main survey was commenced, preliminary assessments were made to identify the households having chicken in the study areas. From each purposively selected kebeles, 30 households that possessed chickens were considered for the survey study. Thus, a total of 90 households were included in the survey.

\section{Method of Data Analysis}

Qualitative and quantitative data sets were analyzed using SPSS, version 16 [15], a computer based statistical program. Descriptive statistics were used to describe quantitative factors while percentage was used for describing qualitative characteristics.

\section{RESULTS AND DISCUSSION}

\section{A. Socio-Economic characteristics}

Table1: Socio-economic characteristics of respondents (\% house hold)

\begin{tabular}{|c|c|c|c|c|c|}
\hline \multirow[b]{2}{*}{ Parameters } & \multirow{2}{*}{$\begin{array}{ll}\text { No. } & \text { of } \\
\text { Respondents }\end{array}$} & \multicolumn{4}{|c|}{ Kebeles (\%) } \\
\hline & & $\begin{array}{l}\text { Buchach }(\%) \\
\mathrm{N}=30\end{array}$ & $\begin{array}{l}\text { Endebera }(\%) \\
\mathrm{N}=30\end{array}$ & $\begin{array}{l}\text { Wurerber }(\%) \\
\mathrm{N}=30\end{array}$ & $\begin{array}{l}\text { Overall }(\%) \\
\mathrm{N}=90\end{array}$ \\
\hline \multicolumn{6}{|l|}{ Age structure } \\
\hline Ø 18-35 & 24 & 26.7 & 26.7 & 26.7 & 26.7 \\
\hline$\varnothing 35-45$ & 37 & 33.3 & 36.7 & 53.3 & 41.1 \\
\hline$\varnothing>45$ & 29 & 40.0 & 36.7 & 20.0 & 32.2 \\
\hline Total & 90 & 100 & 100 & 100 & 100 \\
\hline \multicolumn{6}{|c|}{ Education (\%) } \\
\hline$\varnothing$ Illiterate & 52 & 56.7 & 60 & 56.7 & 57.8 \\
\hline$\varnothing$ Primary & 21 & 20 & 20 & 30 & 23.3 \\
\hline$\varnothing$ Secondary & 16 & 20 & 20 & 13.3 & 17.8 \\
\hline$\varnothing$ College & 1 & 3.3 & 0 & 0 & 1.1 \\
\hline Total & 90 & 100 & 100 & 100 & 100 \\
\hline \multicolumn{6}{|c|}{ Sex of house hold (\%) } \\
\hline$\varnothing$ Male & 70 & 76.7 & 86.7 & 70 & 77.8 \\
\hline$\varnothing$ Female & 20 & 23.3 & 13.3 & 30 & 22.2 \\
\hline Total & 90 & 100 & 100 & 100 & 100 \\
\hline
\end{tabular}

Socio-economic characteristics of the households in the study area were presented in Table 1. Out of the total house hold interviewed only $22.2 \%$ are headed by female, this shows female are not participating in house hold heading responsibility. More than $41 \%$ of the respondent in this study fall under the age category of $35-45$, which indicate that the involvement of youth is small. Most of the interviewed households $(57.8 \%)$ are illiterate. Whereas, the report of Mekonnen says that large proportion of respondents were within age group of 35-60 years ${ }^{[16]}$. 


\section{B. Types of Breeds}

Table 2: Types of breeds in the study area

\begin{tabular}{|c|c|c|c|c|c|}
\hline \multirow[b]{2}{*}{ Parameters $(\%)$} & \multirow[b]{2}{*}{$\begin{array}{l}\text { No. of } \\
\text { respondents }\end{array}$} & \multicolumn{4}{|c|}{ Kebeles (\%) } \\
\hline & & $\begin{array}{l}\text { Buchach }(\%) \\
N=30\end{array}$ & $\begin{array}{l}\text { Endebera(\%) } \\
\mathrm{N}=30\end{array}$ & $\begin{array}{l}\text { Wurerber (\%) } \\
\mathrm{N}=30\end{array}$ & $\begin{array}{l}\text { Overall (\%) } \\
\mathrm{N}=90\end{array}$ \\
\hline Local breeds & 29 & 23.3 & 26.7 & 46.7 & 32.2 \\
\hline Saso breeds & 60 & 73.4 & 73.3 & 53.3 & 66.7 \\
\hline Bovans breed & 1 & 3.3 & 0 & 0 & 1.1 \\
\hline Total & 90 & 100 & 100 & 100 & 100 \\
\hline \multicolumn{6}{|c|}{ Type of chicken reared } \\
\hline Broiler & 5 & 6.7 & 3.3 & 6.7 & 5.6 \\
\hline Chicken & 13 & 16.7 & 16.7 & 10 & 14.4 \\
\hline Layer & 65 & 63.3 & 76.7 & 76.7 & 72.2 \\
\hline Pullet & 7 & 13.3 & 3.3 & 6.7 & 7.8 \\
\hline Total & 90 & 100 & 100 & 100 & 100 \\
\hline \multicolumn{6}{|c|}{ No of eggs collected per year } \\
\hline$<150$ & 3 & 0 & 6.7 & 3.3 & 3.3 \\
\hline $150-180$ & 50 & 56.7 & 43.3 & 66.7 & 55.6 \\
\hline $180-200$ & 37 & 43.3 & 50 & 30 & 41.1 \\
\hline Total & 90 & 100 & 100 & 100 & 100 \\
\hline
\end{tabular}

Table 2 indicated that, the data collected from respondents shows in the study area were about $66.7 \%$ were Saso breed and most type of chicken reared were layer because most their breed were exotic. These chickens were high production performance than local breed. The availability of these breeds type were the achievement Gubre chicken production farm. These results agree with (Fasil) said that, Saso breed is a commercial breed originated from France and it has distributed to different regions of Ethiopia ${ }^{[17]}$. The Reproductive cycle takes longest time for indigenous than exotic chickens because they require long time to reach sexual maturity age and replace parent stock by traditional broody hens which require long time to recover the reproductive cycle.

\section{Poultry production system in the study area}

Table3: Poultry production system in the study area

\begin{tabular}{|l|l|l|l|l|l|l|}
\hline \multirow{2}{*}{ Production System } & \multirow{2}{*}{$\begin{array}{l}\text { No of } \\
\text { respondents }\end{array}$} & $\begin{array}{l}\text { Buchach } \\
\mathrm{N}=30\end{array}$ & $\mathbf{( \% )}$ & $\begin{array}{l}\text { Endebera } \\
\mathrm{N}=30\end{array}$ & $\begin{array}{l}\text { Wurerber } \\
\mathrm{N}=30\end{array}$ & $\begin{array}{l}\text { Overall } \\
\text { N=90 }\end{array}$ \\
\hline Extensive & 81 & 93.3 & 83.3 & 93.3 & 90 \\
Semi intensive & 9 & 6.7 & 16.7 & 6.7 & 10 \\
\hline Total & 90 & 100 & 100 & 100 & 100 \\
\hline
\end{tabular}

Chicken production system available in the study area is indicated in Table 3. According to this finding, chicken production system in the area shows clear distinction between traditional and intensive chicken production system. Among all interviewed households $90 \%$ practice free scavenging or/and extensive chicken production system and $10 \%$ of the respondent practice semi-intensive poultry production system. These studies agree with Dawite, said that most of village chicken production in Ethiopia is generally characterized by extensive production system ${ }^{[18]}$.

D. Purpose of keeping chicken and egg production

Table 4: Priorities in Purpose of chicken keeping in the study area

\begin{tabular}{|c|c|c|c|c|c|}
\hline \multirow[b]{2}{*}{ Parameters } & \multirow{2}{*}{$\begin{array}{l}\text { No. of } \\
\text { Respondents }\end{array}$} & \multicolumn{3}{|c|}{ Kebeles (\%) } & \multirow{2}{*}{$\begin{array}{l}\text { Overall } \quad(\%) \\
\mathrm{N}=90\end{array}$} \\
\hline & & $\begin{array}{l}\text { Buchach }(\%) \\
\mathrm{N}=30\end{array}$ & $\begin{array}{l}\text { Endebera (\%) } \\
\mathrm{N}=30\end{array}$ & $\begin{array}{l}\text { Wurerber }(\%) \\
\mathrm{N}=30\end{array}$ & \\
\hline \multicolumn{6}{|c|}{ Purpose of rearing chicken } \\
\hline Consumption & 29 & 33.3 & 36.7 & 26.7 & 32.2 \\
\hline Selling & 60 & 66.7 & 60 & 73.3 & 66.7 \\
\hline Both & 1 & 0 & 3.3 & 0 & 1.1 \\
\hline Total & 90 & 100 & 100 & 100 & 100 \\
\hline \multicolumn{6}{|c|}{ Purpose of egg production } \\
\hline Consumption & 17 & 20 & 20 & 16.7 & 18.9 \\
\hline Selling & 70 & 73.3 & 76.7 & 83.3 & 77.8 \\
\hline Hatching & 3 & 6.7 & 3.3 & 0 & 3.3 \\
\hline Total & 90 & 100 & 100 & 100 & 100 \\
\hline
\end{tabular}

Purpose of keeping chicken in different study areas of the households is shown in Table 4. The purposes of keeping of chicken by the households were various types across study areas. Generally the respondent in the study 
area gave priority for income generation.

\section{E. Responsibility sharing in chicken production}

Table 5: Responsibility Sharing in Chicken Production in the Study area.

\begin{tabular}{|c|c|c|c|c|c|}
\hline \multirow[b]{2}{*}{$\begin{array}{l}\text { Feeding, Watering } \\
\text { and Selling of } \\
\text { chicken }\end{array}$} & \multirow[b]{2}{*}{$\begin{array}{l}\text { No. of } \\
\text { Respondents }\end{array}$} & \multicolumn{3}{|c|}{ Kebeles (\%) } & \multirow[b]{2}{*}{$\begin{array}{l}\text { Overall } \\
(\%) \\
\mathrm{N}=90\end{array}$} \\
\hline & & $\begin{array}{l}\text { Buchach } \quad(\%) \\
\mathrm{N}=30\end{array}$ & $\begin{array}{l}\text { Endebera }(\%) \\
N=30\end{array}$ & $\begin{array}{l}\text { Wurerber } \\
(\%) \\
\mathrm{N}=30\end{array}$ & \\
\hline $\begin{array}{l}\text { Women } \\
\text { Men } \\
\text { Children }\end{array}$ & $\begin{array}{l}79 \\
47\end{array}$ & $\begin{array}{l}93.3 \\
3.3 \\
3.3 \\
\end{array}$ & $\begin{array}{l}80 \\
6.7 \\
13.3 \\
\end{array}$ & $\begin{array}{l}90 \\
3.3 \\
6.7 \\
\end{array}$ & $\begin{array}{l}87.8 \\
4.4 \\
7.8 \\
\end{array}$ \\
\hline Total & 90 & 100 & 100 & 100 & 100 \\
\hline
\end{tabular}

According to the current study out of the total respondent interviewed (66.7\%) raise chicken for the purpose of income generation by selling live chicken and eggs and the other (32.2\%) gave secondary importance. These results agree with Dessalew, Selling of live chicken and eggs for generating income was given higher priority ${ }^{[19]}$.

F. Source of feed in the study area

Table 6: Sources of supplementary feed and way of supplementation in the study area.

\begin{tabular}{|c|c|c|c|c|c|}
\hline \multirow[b]{2}{*}{ Parameters $(\%)$} & \multirow[b]{2}{*}{$\begin{array}{l}\text { No of } \\
\text { respondents }\end{array}$} & \multicolumn{3}{|c|}{ Kebeles (\%) } & \multirow[b]{2}{*}{$\begin{array}{l}\text { Overall }(\%) \\
\mathrm{N}=90\end{array}$} \\
\hline & & $\begin{array}{l}\text { Buchach }(\%) \\
\mathrm{N}=30\end{array}$ & $\begin{array}{l}\text { Endebera }(\%) \\
\mathrm{N}=30\end{array}$ & $\begin{array}{l}\text { Wurerber }(\%) \\
\mathrm{N}=30\end{array}$ & \\
\hline \multicolumn{6}{|l|}{ Source of feed } \\
\hline From the house/ left over & 61 & 70 & 60 & 73.4 & 67.8 \\
\hline Purchased & 27 & 30 & 36.7 & 23.3 & 30 \\
\hline Purchase and from the house & 2 & 0 & 3.3 & 3.3 & 2.2 \\
\hline Total & 90 & 100 & 100 & 100 & 100 \\
\hline \multicolumn{6}{|l|}{ Way of supplementation } \\
\hline Separate to different classes & 70 & 76.7 & 80 & 76.7 & 77.8 \\
\hline $\begin{array}{l}\text { Together for } \\
\text { whole group }\end{array}$ & 20 & 23.3 & 20 & 23.3 & 22.2 \\
\hline Total & 90 & 100 & 100 & 100 & 100 \\
\hline \multicolumn{6}{|l|}{ Basis to give supplements } \\
\hline Egg yield & 71 & 27.8 & 32.2 & 40 & 78.9 \\
\hline Meat yield & 2 & 2.2 & 0 & 0 & 2.2 \\
\hline Egg and meat & 17 & 70 & 67.8 & 60 & 18.9 \\
\hline Total & 90 & 100 & 100 & 100 & 100 \\
\hline
\end{tabular}

In the study area women share the responsibility of chicken feeding, watering and selling in the market; women dominated as $87.8 \%$, children $7.8 \%$, Men $4.4 \%$. Abubakar also described that women and children contribution was by far the highest on village flocks management labor profile activities in some parts of Nigeria and Cameroon ${ }^{[20]}$. Mapiye also reported that women in Zimbabwe were dominated in most village chicken production activities ${ }^{[21]}$.

Table 6 indicated that respect to the source of supplementary feed, $67.8 \%$ of left over obtained supplementary feed from their own harvest $30 \%$ market, and $2.2 \%$ used both left over and market and the way of supplementation were 77.8 in Separate to different classes, $22.2 \%$ of Together for the whole group and Basis to give supplements $78.9 \%$ Egg yield, Meat yield $2.2 \%$ and $18.9 \%$ Egg and meat. These results agree with Mapiye and Sibada reported that in rushing district of Ethiopia, most farmers (95.5\%) produce their own supplementary feeds, and $4.5 \%$ use purchased feed and the portion that comes as grain supplement varied with seasons and activities and also the way to supplementation of feed were in different class based on age and their purpose ${ }^{[21]}$. Halima also reported that 99.3\% of chicken owners in North West Amhara Region provided supplementary feeds to village birds ${ }^{[22]}$.

\section{G. Supplementary feed source}

Table 7: Supplementary feed source in the study area.

\begin{tabular}{|c|c|c|c|c|c|}
\hline \multirow{3}{*}{ Source of feed } & \multirow{3}{*}{$\begin{array}{l}\text { No of } \\
\text { respondents }\end{array}$} & \multirow{2}{*}{\multicolumn{3}{|c|}{ Kebeles(\%) }} & \multirow[b]{3}{*}{$\begin{array}{l}\text { Overall } \quad(\%) \\
\mathrm{N}=90\end{array}$} \\
\hline & & & & & \\
\hline & & $\begin{array}{l}\text { Buchach } \quad(\%) \\
N=30\end{array}$ & $\begin{array}{l}\text { Endebera } \\
\mathrm{N}=30\end{array}$ & $\begin{array}{l}\text { Wurerber } \\
\mathrm{N}=30\end{array}$ & \\
\hline wheat & 4 & 3.3 & 6.7 & 3.3 & 4.4 \\
\hline Maize & 57 & 56.7 & 56.7 & 76.7 & 63.4 \\
\hline Amicho & 29 & 40 & 36.7 & 20 & 32.2 \\
\hline Total & 90 & 100 & 100 & 100 & 100 \\
\hline
\end{tabular}

The table indicates the data collected from respondents shows that there are four types of feed source.63.4\%of the respondents reported that their feed source was maize; out of 32.2\% used Amicho, $4.4 \%$ used wheat as feed 
source for their chickens.

\section{H. Provision of water}

Table 8: Water provision for village chickens in the study area.

\begin{tabular}{|l|l|l|l|l|l|}
\hline \multirow{2}{*}{ Water provision } & \multirow{2}{*}{$\begin{array}{l}\text { No of } \\
\text { respondents }\end{array}$} & $\begin{array}{l}\text { Buchach (\%) } \\
\mathrm{N}=30\end{array}$ & $\begin{array}{l}\text { Endebera (\%) } \\
\mathrm{N}=30\end{array}$ & $\begin{array}{l}\text { Wurerber } \\
\mathrm{N}=30\end{array}$ & $\begin{array}{l}\text { Overall } \\
\text { N=90 }\end{array}$ \\
\hline No provision & 34 & 40 & 33.3 & 40 & 37.8 \\
By a dish & 56 & 60 & 66.7 & 60 & 62.2 \\
\hline Total & 90 & 100 & 100 & 100 & 100 \\
\hline
\end{tabular}

The study result also revealed that, about $62.2 \%$ of the total households provided water for chicken by dish and $37.8 \%$ of the total households provided water for chicken with no provision. These results also agree with Dessalew reports that most village chicken are gain water by a dish, wooden bamboo etc. ${ }^{[19]}$.

I. Housing of village chicken in the study area Table 9: Housing of village chicken in the study area

\begin{tabular}{|c|c|c|c|c|c|}
\hline \multirow[b]{2}{*}{ Parameters $(\%)$} & \multirow{2}{*}{$\begin{array}{l}\text { No of } \\
\text { respondents }\end{array}$} & \multicolumn{3}{|c|}{ Kebeles(\%) } & \multirow[b]{2}{*}{$\begin{array}{l}\text { Overall }(\%) \\
\mathrm{N}=90\end{array}$} \\
\hline & & $\begin{array}{l}\text { Buchach }(\%) \\
\mathrm{N}=30\end{array}$ & $\begin{array}{l}\text { Endebera }(\%) \\
\mathrm{N}=30\end{array}$ & $\begin{array}{l}\text { Wurerber }(\%) \\
\mathrm{N}=30\end{array}$ & \\
\hline \multicolumn{6}{|l|}{ Separate house } \\
\hline Yes & 26 & 36.7 & 10 & 40 & 28.9 \\
\hline No & 64 & 63.3 & 90 & 60 & 71.1 \\
\hline Total & 90 & 100 & 100 & 100 & 100 \\
\hline \multicolumn{6}{|l|}{ Night shelter of chicken } \\
\hline Perch inside the house & 77 & 83.3 & 80 & 93.3 & 85.6 \\
\hline In separate house & 13 & 16.7 & 20 & 6.7 & 14.4 \\
\hline Total & 90 & 100 & 100 & 100 & 100 \\
\hline \multicolumn{6}{|c|}{ Reason not construct separate house } \\
\hline Lack of awareness & 65 & 63.3 & 90 & 63.3 & 73.2 \\
\hline Lack of capital & 25 & 36.7 & 10 & 33.3 & 26.8 \\
\hline Total & 90 & 100 & 100 & 100 & 100 \\
\hline
\end{tabular}

Table 9 indicates the data collected from respondents shows in the study area were about $71.1 \%$ of the respondents have no separate chicken house, $85.6 \%$ Perch inside the house and $73.2 \%$ Lack of awareness about housing system .This indicates that the owners are not aware of the importance of housing. These results agree with Dwinger, he said that, lack of housing is one of the constraints of the village exotic chicken production systems [23]. In some African countries, a large proportion of village chicken mortality accounted due to nocturnal predators because of lack of proper housing. Some research works also indicated that the mortality of scavenging birds reduced by improved housing.

\section{J. Type of predator and disease}

Table 10: Type of Predator and Disease in the Study area.

\begin{tabular}{|c|c|c|c|c|c|}
\hline \multirow[b]{2}{*}{$\begin{array}{l}\text { Type of } \\
\text { Predator }\end{array}$} & \multirow[b]{2}{*}{$\begin{array}{ll}\text { No } & \text { of } \\
\text { respondents }\end{array}$} & \multicolumn{3}{|c|}{ Kebeles( $(\%)$} & \multirow[b]{2}{*}{$\begin{array}{l}\text { Overall } \quad(\%) \\
\mathrm{N}=90\end{array}$} \\
\hline & & $\begin{array}{l}\text { Buchach (\%) } \\
\mathrm{N}=30\end{array}$ & $\begin{array}{l}\text { Endebera (\%) } \\
\mathrm{N}=30\end{array}$ & $\begin{array}{l}\text { Wurerber (\%) } \\
\mathrm{N}=30\end{array}$ & \\
\hline Cat & 3 & 6.7 & 3.3 & 0 & 3.3 \\
\hline Dog & 1 & 3.3 & 0 & 0 & 1.1 \\
\hline Eagle & 15 & 13.3 & 20 & 16.7 & 16.7 \\
\hline Shelemetmat & 71 & 76.7 & 76.7 & 83.3 & 78.9 \\
\hline Total & 90 & 100 & 100 & 100 & 100 \\
\hline \multicolumn{6}{|c|}{ Any disease occurrence in the farm } \\
\hline Yes & 87 & 93.3 & 96.7 & 100 & 96.7 \\
\hline No & 3 & 6.7 & 3.3 & 0 & 3.3 \\
\hline Total & 90 & 100 & 100 & 100 & 100 \\
\hline \multicolumn{6}{|l|}{ Main diseases } \\
\hline $\mathrm{NCD}$ & 70 & 76.7 & 86.7 & 70 & 77.8 \\
\hline Parasite & 20 & 23.3 & 13.3 & 30 & 22.2 \\
\hline Total & 90 & 100 & 100 & 100 & 100 \\
\hline
\end{tabular}

Table10 indicates the data collected from respondents shows in the study area Shelemetmat 78.9\%, eagle $16.7 \%$, cat $3.3 \%$, dog $1.1 \%$, so that the table indicate the main predator was Shelemetmat because of most of their management system were extensive. And the most serious disease was NCD $77.8 \%$, parasite $22.2 \%$. Because 
of their feeding system were free range and contact with different flock . The result were agree with Terefe, said that Newcastle disease was most widely distributed among the village chicken in Ethiopia [24] and Tadelle and Ogle said that, high mortality of chicks under village chicken production in the central highlands of Ethiopia was due to diseases, parasites, predation, lack of feed, poor housing and insufficient water supply [13]. Similarly, different scholars [25; 22 and 26] reported NCD was the major disease affecting village chicken production in different parts of Ethiopia.

\section{K. Major constraints in village chicken production}

Table 11: Major constraints in village chicken production

\begin{tabular}{|l|l|l|l|l|l|}
\hline \multirow{2}{*}{ Parameters (\%) } & \multirow{2}{*}{$\begin{array}{l}\text { No of } \\
\text { respondents }\end{array}$} & $\begin{array}{l}\text { Buchach (\%) } \\
\text { N=30 }\end{array}$ & $\begin{array}{l}\text { Endebera } \\
(\%) \mathrm{N}=30\end{array}$ & $\begin{array}{l}\text { Wurerber (\%) } \\
\text { N=30 }\end{array}$ & $\begin{array}{l}\text { Overall } \\
\text { N=90 }\end{array}$ \\
\hline Disease & 11 & 6.7 & 23.4 & 6.7 & 12.2 \\
Feed scarcity & 1 & 0 & 3.3 & 0 & 1.1 \\
Housing & 77 & 90 & 73.3 & 93.3 & 85.6 \\
Management & 1 & 3.3 & 0 & 0 & 1.1 \\
\hline Total & 90 & 100 & 100 & 100 & 100 \\
\hline
\end{tabular}

Table11 indicates the data collected from respondents shows in the study area were, the main constraints about $85.6 \%$ were housing system. The problem of disease in village chickens is compounded by the interaction of different entities that are significant importance of disease epidemiology. These study were agree with ${ }^{[12 ; 27]}$ said that, At village level, contacts between flocks of different households, were the main sources of infection transmission because of in adequate housing system.

\section{Extension services and training}

Table 12: Extension services and training

\begin{tabular}{|c|c|c|c|c|c|}
\hline \multirow[b]{2}{*}{ Parameters } & \multirow{2}{*}{$\begin{array}{l}\text { No of } \\
\text { respondents }\end{array}$} & \multicolumn{3}{|c|}{ Kebeles $(\%)$} & \multirow{2}{*}{$\begin{array}{l}\text { Overall } \quad(\%) \\
\mathrm{N}=90\end{array}$} \\
\hline & & $\begin{array}{l}\text { Buchach }(\%) \\
\mathrm{N}=30\end{array}$ & $\begin{array}{l}\text { Endebera } \\
\mathrm{N}=30\end{array}$ & $\begin{array}{l}\text { Wurerber } \quad(\%) \\
\mathrm{N}=30\end{array}$ & \\
\hline \multicolumn{6}{|c|}{ Got extension services } \\
\hline Yes & 25 & 20 & 23.3 & 40 & 27.8 \\
\hline No & 65 & 80 & 76.7 & 60 & 72.2 \\
\hline Total & 90 & 100 & 100 & 100 & 100 \\
\hline \multicolumn{6}{|l|}{ Training took } \\
\hline Yes & 30 & 30 & 43.3 & 26.7 & 33.3 \\
\hline No & 60 & 70 & 56.7 & 73.3 & 66.7 \\
\hline \multicolumn{6}{|l|}{ Training on } \\
\hline Health care & 60 & 68.7 & 56.7 & 73.3 & 66.7 \\
\hline Housing & 30 & 31.3 & 43.3 & 26.7 & 33.3 \\
\hline Total & 90 & 100 & 100 & 100 & 100 \\
\hline
\end{tabular}

Table 12 indicates the data collected from respondent's shows in the study area were $27.8 \%$ got extension service, $72.2 \%$ not got extension services and 33.3\% training took, $66.7 \%$ no training took. These indicates that farmer were in adequate Extension education on aspect of chicken production. And they were Training on $66.7 \%$ Health care and $33.3 \%$ Housing system, most of them were unskilled in housing system because they were less awareness about housing system. These studies also agree with Desalew said that, lack of housing system one of the constraints of village chicken production system ${ }^{[19]}$. 


\section{Veterinary service}

Table 13: Veterinary service in the study area.

\begin{tabular}{|c|c|c|c|c|c|}
\hline \multirow[b]{2}{*}{ Parameters } & \multirow{2}{*}{$\begin{array}{l}\text { No of } \\
\text { respondents }\end{array}$} & \multicolumn{3}{|c|}{ Kebeles(\%) } & \multirow[b]{2}{*}{$\begin{array}{l}\text { Overall } \quad(\%) \\
\mathrm{N}=90\end{array}$} \\
\hline & & $\begin{array}{l}\text { Buchach }(\%) \\
\mathrm{N}=30\end{array}$ & $\begin{array}{l}\text { Endebera(\%) } \\
\mathrm{N}=30\end{array}$ & $\begin{array}{l}\text { Wurerber(\%) } \\
\mathrm{N}=30\end{array}$ & \\
\hline \multicolumn{6}{|c|}{ Identification of sick chickens } \\
\hline Diarrhea & 53 & 53.3 & 63.3 & 60 & 58.9 \\
\hline Stand feather & 37 & 46.7 & 36.7 & 40 & 41.1 \\
\hline Total & 90 & 100 & 100 & 100 & 100 \\
\hline \multicolumn{6}{|c|}{ Treatment/vaccination } \\
\hline Traditional & 73 & 80 & 80 & 83.3 & 81.1 \\
\hline Modern & 17 & 20 & 20 & 16 & 18.9 \\
\hline Total & 90 & 100 & 100 & 100 & 100 \\
\hline \multicolumn{6}{|c|}{ Traditional medicine used } \\
\hline Areke & 33 & 20 & 46.7 & 43.3 & 36.7 \\
\hline Lemon & 57 & 80 & 53.3 & 56.7 & 63.3 \\
\hline Total & 90 & 100 & 100 & 100 & 100 \\
\hline
\end{tabular}

Table13 indicates Vaccination/treatment in the study area of sick chickens identify by $58.9 \%$ Diarrhea, $41.1 \%$ Stand their feather and the way of Treatment/vaccination were $81.1 \%$ by Traditional, $18.9 \%$ by Modern and To treat their sick chickens, half of the owners used traditional remedies, which were usually administered through they used $63.3 \%$ Lemon and $36.7 \%$ Areke. Whereas, a few use or treated by veterinarian access medicine. These results agree with Fisseha said that, the level of awareness about availability of vaccines for local chicken is low and the farmers do not have any experience of getting their chicken vaccinated against diseases [28]. This is due to the fact that the farmers have no information about disease control and vaccination because of poor extension package of chicken production.

N. Marketing of chicken and chicken products

Table 14: Market determinants of chicken price and their demand in the study area

\begin{tabular}{|c|c|c|c|c|c|}
\hline \multirow[b]{2}{*}{ Parameters $(\%)$} & \multirow[b]{2}{*}{$\begin{array}{l}\text { No of } \\
\text { respondents }\end{array}$} & \multicolumn{3}{|c|}{ Kebeles $(\%)$} & \multirow[b]{2}{*}{$\begin{array}{l}\text { Overall } \quad(\%) \\
\mathrm{N}=90\end{array}$} \\
\hline & & $\begin{array}{l}\text { Buchach } \\
(\%) \mathrm{N}=30\end{array}$ & $\begin{array}{l}\text { Endebera }(\%) \\
\mathrm{N}=30\end{array}$ & $\begin{array}{l}\text { Wurerber } \\
\mathrm{N}=30\end{array}$ & \\
\hline \multicolumn{6}{|c|}{ Marketing system of chicken products and their demand. } \\
\hline $\begin{array}{l}\text { Festival } \\
\text { Non festival }\end{array}$ & $\begin{array}{l}60 \\
30\end{array}$ & $\begin{array}{l}68.7 \\
31.3\end{array}$ & $\begin{array}{l}56.7 \\
43.3\end{array}$ & $\begin{array}{l}73.3 \\
26.7\end{array}$ & $\begin{array}{l}66.7 \\
33.3\end{array}$ \\
\hline Total & 90 & 100 & 100 & 100 & 100 \\
\hline
\end{tabular}

Table 14 indicates in the study area were Marketing system of chicken products and their demand in festival day $66.7 \%$, Non festival day $33.3 \%$ because the demand of chicken were dominants mainly around Christmas, ester and new year. These study agree with (Amsalu) who reported that, in most countries, the village chicken and egg are highly prized in the festival day The sale of chickens is mainly important around Christmas or in case of emergencies, Muslim holydays are equally important when it comes to chicken or egg sale ${ }^{[29]}$ and, Tadele said that, the proportion of sale is more to the poorer households, who depend more on the income from sale of eggs and chickens compared to wealthy households who consume more ${ }^{[6]}$.

\section{CONCLUSION}

This study was focused on management practices, constraints, opportunities and marketing systems of village chicken production in central Ethiopia and covers selected kebeles purposively and a total of 90 purposively selected households were used. Poultry production is experienced by every farmers as side line with other farming activities and offer farmers with further income, and also used as initial point for young to start business idea. From the results, both males and females were highly participated in chicken farming activity. The purposes of keeping chicken by households were for sales followed by home consumption and hatching. Extensive is the major feeding methods followed by semi intensive production system which are supplemented maize, wheat and amicho usually during morning and evening times. Women play major role in the ownership of decision making to sale chicken and egg, feeding and watering, cleaning chicken house, treating sick chicken while men's dominate in preparation of night resting place and or a partition in the house.

The result of the present study revealed that chicken production in the study area was hindered due to poor management like diseases, feed scarcity, housing and predators. Therefore it is concluded that information should be disseminating to smallholder farmers about chicken husbandry and government should provide vaccine and expansion of veterinary service, and extension package for intervention to increase the productivity and economics contribution of poultry should also be designed. Based on the above conclusion, the following recommendations 
were forwarded:

$>$ Livestock and Fishery Resource office and development agents should provide training in management of different chicken husbandry system like feed management, provision of improved housing, disease control, market etc. and entrepreneurship could support to improve productivity of chicken.

$>$ The tricky of predators could be minimized by resounding farmers to construct and housing chicken in predator proof separate chicken houses, especially during the night.

$>$ Meanwhile as most of village chicken production activity is managed by women, provision of successive trainings on modern chicken husbandry practices and poultry extension activities need to be targeted towards women would be essential for the improvement of chicken production and productivity.

\section{REFERENCES}

[1] Alders R. Poultry for profit and pleasure. FAO Diversification Booklet 3. FAO (Food and Agriculture Organization of the United Nations), Rome, Italy, 2004.

[2] Deressa, T., Hassan, R.M., Alemu, T., Yusuf, M.and Ringler, C. Analyzing the Determinants of Farmers ${ }^{\text {ee }}$ Choice of Adaptation Methods and Perceptions of Climate Change in the Nile Basin of Ethiopia. IFPRI Discussion Paper 00798:1-26, (2008).

[3] Solomon, Z., Binyam, K., Bilatu, A. and Ferede, A. Village chicken production systems in Metekel zone, Northwest Ethiopia. Wudpecker J.Agri.Res., 2(9):256-262. 2013.

[4] Muchadeyi, F.C., Wollny CBA. , Eding, H., Weigend, S., Makuza, S.M. and Simianer, H.: Variation in village chicken production systems among agro ecological zones of Zimbabwe. Trop. Anim. Health Prod.39:453546 (2007).

[5] Addo. Improving Farm Yard Poultry Production in Africa.2003.

[6] Tadelle D, Million T, Alemu Y, Peters KJ. Village chicken production systems in Ethiopia Use patterns and performance valuation and chicken products and socio-economic functions of chicken. Livestock Research for Rural Development(2003).

[7] Nigussie, D., Van der waaij, L., Dessie, T. and Van Arendonk, J. Production objectives and trait preferences of village poultry producers of Ethiopia: implications for designing breeding schemes utilizing indigenous chicken genetic resources. Trop. Anim. Health prod., 42: 519-529(2010).

[8] Solomon, D. Growth performance and survival of local and white leghorn chickens under scavenging and intensive systems of management in Ethiopia. Livestock research for rural development (15) 11(2003).

[9] Dhuguma, R.: Understanding the role of indigenous chickens during the long walk to food security in Ethiopia. Livestock research for rural development(2009).

[10] Muchadey, Halima Kassaby, and Dessie Village Chicken Flock Dynamics and the contribution of chicken to household livelihoods, in a small holder farming area in Zimbabwe Trop Animal Health Production.2005.

[11] Natnael, T. Pathological and Seroprevalence Studies On Infectious Bursal Disease in Chickens in and Around Bahir Dar, North West, Ethiopia. M.Sc. Thesis, Addis Ababa University, College of Veterinary Medicine and Agriculture, Department of Pathology and Parasitological, Bishoftu, Ethiopia(2015).

[12] Tadelle. Village chicken production system in Ethiopia(2003).

[13] Tadelle and Ogle, Village Poultry Production System in Central Highland of Ethiopia; use patterns and performance evaluation and chicken products and socioeconomic function of chicken2001.

[14] DHiAlchalabi, Monitoring Poultry House Environments(2001).

[15] SPSS (Statistical Package for Social Sciences) (2007) SPSS for windows. User's guide Statistics version 16.

[16] Mekonnen, G. Characterization of the Small Holder Poultry Production and Marketing System of Dale, Wonsho and Lokaabaya Were as of SNNPRS(2007).

[17] Fasil, Preliminary Information on Chicken Strains to be tested in Ethiopia. African Chicken Genetic (2016).

[18] Dawit, A., Overview and background paper on Ethiopia's poultry sector. Relevance for HPAI Research in Ethiopia(2008).

[19] Desalew, T.: Management Practices, Productive Performances and Egg Quality Traits of Exotic Chickens under Village Production System in East Shewa, Ethiopia. M.Sc.Thesis, Addis Ababa University, College of Veterinary Medicine and Agriculture, DebreZeit, Ethiopia(2012).

[20] Abubakar MB, Ambali AG and Tamjdo T. Rural chicken production: Effects of gender on ownership, and management responsibilities in some parts of Nigeria and Cameroon. International Journal of Poultry Science 6(6):413-4162007.

[21] Mapiye, C, and S, Sibanda. Constraints and Opportunities of Village Chicken Production System in Small Holder Sector of Rushinga District of Zimbabwe Livestock, Res Rural Dal, 17/10/ Accessed: 04/11/2005.

[22] Halima HM. Phenotypic and genetic characterization of indigenous chicken populations in North-West Ethiopia. Ph.D Thesis. Submitted to the faculty of natural and agricultural sciences department of animal, wildlife and grassland Sciences. University of the Free State, Bloemfontein, South Africa(2007).

[23] Dwinger, R.H., Bell, J.G. and Permin, A. A program to improve family poultry production in Africa. B.P. 
6268, Rabat-Institutes, Morocco(2003).

[24] Terefe, D., Redeat, B., Hassen, C., Melaku, S., Abebe, M., Getachew, G., Kumela, L. and Delesa, D. Serological and molecular study of new castle disease virus in village chickens in selected Rift Valley Areas, Ethiopia. J. Vet. Sci Technol. 6:264. (2015).

[25] Moges F., Abera M. and Tadelle D., Assessment of village chicken production system and evaluation of the productive and reproductive performance of local chicken ecotype in Bure district, North West Ethiopia. Afr. J. Agric. Res. 2010.

[26] Serkalem T, Hagos A, Zeleke A. Sero-prevalence study of Newcastle disease in local chickens in central Ethiopia. Inter. J. Appl. Res. Vet. Med., 3: 1. (2005).

[27] Mapiye and Sibanda, Village Chicken production system in rural Africa household food security and gender issue. Food and Agriculture Organization of the United Nations, Rome. 2003.

[28] Fisseha, M., Azage, T. and Tadelle, D. Indigenous chicken production and marketing systems in Ethiopia: Characteristics and opportunities for market-oriented development. IPMS (Improving Productivity and Market Success) of Ethiopian Farmers Project Working Paper 24.Nairobi, Kenya, ILRI. 2010.

[25] Amsalu, A., Practical Poultry Training Manual (Unpublished) Amhara region agriculture research institute, Kombolcha Poultry Research and Multiplication enter.2003.

\section{AUTHOR}

Author: Tena Alemu, Msc in Animal Production, Hawassa University, Ethiopia 